\title{
The Potential Impact and Influence of Private Higher Education Institutions in the Internationalization of Higher Education in South Africa
}

\author{
Prem Ramlachan ${ }^{1, *}$ \\ ${ }^{1}$ Graduate School of Business, 26 Samora Machel Street Durban, South Africa \\ *Corresponding author: Mancosa Graduate School of Business , 26 Samora Machel Street \\ Durban, South Africa. Tel: 27-31300-7200 (Switchboard) E-mail: \\ Publications@mancosa.co.za
}

Received: February 7, 2019 Accepted: March 27, 2019 Published: April 21, 2019

doi:10.5296/ije.v11i2.14699 URL: https://doi.org/10.5296/ije.v11i2.14699

\begin{abstract}
The United Nations Sustainable Development Goal 4 advocates the need for inclusive and equitable quality education, which will promote life-long learning opportunities for all. Globally, however, the demand for access to higher education exceeds the places which are available, resulting in many students who cannot obtain places in institutions and in their respective programmes of choice.
\end{abstract}

A case study research method was utilized, using a private higher education institution (HEI), referred to here as "Institution Y". The empirical part of the search focused on engaging in dialogue with some of the directors based on their experience by retrieving information around the internationalisation of private higher education.

South Africa, in its quest to be the preferred destination of choice to study and research, has to discover a working basis that is universal in its application. Arguments influencing inclusivity, equality and life-long learning focuses around conceptualisation, foot-printing and agility, surfaced in the study.

The potential impact and influence of private HEIs on internationalisation of higher education can only be aligned with Goal 4 if re-conceptualisation, increasing the international footprint and agility, is driven aggressively for the greater good of the South African higher education.

It is advocated, amongst other recommendations, that private and public higher educations be strengthened systemically in South Africa, so that it becomes the destination of choice for higher education to realise Sustainable Development Goal 4.

Keywords: Internationalization, Higher Education, Inclusivity, Access, Life-Long Learning, Conceptualization, International Footprint 


\section{Introduction}

The United Nations Sustainable Development Goal 4 (SDG4, 2015) advocates the need "To ensure inclusive and equitable quality education, and promote life-long learning opportunities for all". Globally, however, the demand for access to higher education (HE) exceeds the places which are available, especially in public higher education, resulting in many students who cannot obtain places in institutions and in their respective programmes of choice, which is contrary to the spirit of Goal 4. The Department of Higher Education and Training's Strategic Plan is to diversify provision based on open learning principles. This aims to improve learning opportunities across the post-school education and training sector by expanding and strengthening the post-school distance education landscape (DHET, 2015/2016-2019/20). The National Development Plan (NDP, 2030) reports that in nearly every facet of life, advances are being made in building an inclusive society, rolling back the shadows of history and broadening opportunities for all. However, the Plan is silent about the role of Private HEIs which offer distance learning.

\subsection{Scepticism and Regulations}

While the capabilities of increasing access to higher education are possible through private higher education, scepticism and regulations are barriers to exploiting these capabilities. Historically, private HEIs in a global context several decades ago were a major force in the higher education realm. Now, in the last quarter of the $20^{\text {th }}$ century, the dynamics have changed dramatically. Private higher education has now become the fastest growing segment of higher education worldwide (Altbach 2005:1). Many universities across the world include major discoveries which are patented and held by private higher education institutions, while scepticism still prevails about them, particularly their standards and cost to students. In this paper, it is argued that private higher education institutions can be inclusive, are generally primed to offer quality higher education programmes and will contribute substantially to addressing, expanding and widening the access to higher education studies. It is further argued that private HE can contribute substantially to internationalisation of higher education in South Africa based on its agility and footprint in international spaces.

\subsection{Access}

Drawing from personal experiences of working in both the public and private sectors within the South African higher education system, expanding and widening access into higher education has a subtle, but fundamental difference. Widening access differs from expanding access, in that widening access has a transformational dimension to inclusivity and an equitable higher education system. In a press release dated 29 January 2014 on "Breaking Barriers" the Regent Business School in Durban, South Africa supported the idea that "private providers can widen access to higher education". In this paper, it is further posited that private HE in South Africa can contribute to both widening and expanding higher education access. The State has the responsibility towards widening access with objectives, goals and aims that make curricula globally open. Social responsibility by the state means opening access from primary education to higher education, while maintaining the quality of higher education studies. However, if the state alone takes on this responsibility, the objectives of Goal 4 may never be realised. Hence 
in this paper, it is also argued that a stronger partnership and benchmarking between public and private higher education is needed to widen, expand and maintain standards that are commensurate with global trends, and that these will contribute to the internationalisation of higher education.

\section{What is Internationalisation in Relation to Higher Education?}

According to Jane Knight (2015: 1), "Internationalization at the national, sector, and institutional levels is defined as the process of integrating international, intercultural, or global dimension into the purpose, functions or delivery of (post-secondary) education". It is that part of higher education that focuses on the broad purpose, functions and delivery of higher education objectives. In this conception, while national imperatives of transformation are crucial, the international and global dimensions into teaching and learning, research and service functions are equally important for credibility, recognition, transferability and knowledge production. Hence the internationalisation of HE should not be lost in the pursuit of national transformational interest.

\subsection{Public Private Partnerships}

While higher education is very complex as it includes various dimensions of power dynamics which are dominated by internal and external politics and the North-South developeddeveloping countries divide, its internationalisation is never a neutral space. What constitutes internationalisation and who drives it and how it is maintained, is a complex web of debates and contestation. It is in this web of debates and contestation that the role and value of private higher education towards achieving Goal 4 of the UNSDG is highlighted. In this paper, the aim is to explore how private and public higher education should be re-conceptualised to minimise scepticism associated with private higher education institutions, so that strong public-private relations and partnerships can be developed. Attention is drawn to some specific features of the providers including public-private partnerships, students studying with privately funded providers, and the governance arrangements among a sample of providers. An assessment of various impacts of privately funded providers on the higher education sector in the UK is made, a major one being the changing structure and dynamic of the sector such that it is no longer possible to sharply distinguish between public and private provision (Middlehurst, 2016). Using "Institution Y" as an example of a private higher education institution, this paper illustrates how strong public-private partnerships can be created, sustained and exploited to meet the growing demands of access to higher education.

"Institution $\mathrm{Y}$ " is a private higher education institution registered in terms of the Higher Education Act, (Act 101 of 1997), as amended. Established in 1995 as a post-apartheid empowerment institution, it offers affordable and accessible management post- graduate education mainly to those previously denied access. It has a $100 \%$ black ownership. 


\section{Private and State Higher Education: Contestations and Opportunities}

The landscape of higher education provisioning internationally includes private and public providers. The existence of these two kinds of providers are as a result of various factors including demand by potential students (Arnold Bakker 2014: on-line: 37-64), business opportunities of entrepreneurs (Entrepreneurs 2015: on-line: 1), competition, cost factors and specialist programme offerings. While these two kinds of providers exist, their relationships and how they are seen by stakeholders varies from antagonistic to symbiotic attitudes (Lewis \& Landis 2013: on-line: 230-249). Unravelling these varying attitudes for and against them is, perhaps a useless activity. What this paper focuses on is how the relationship between private and state higher education can be exploited within the context of high demand for access to education. State and private higher education providers are usually in conflict about the quality of the qualifications and the effect that regulatory compliance has on institutional autonomy. The growing demand for higher education in society, the recognition by students that private providers do provide a service that has positive outcomes, and that the future of education is based on a collaborative model or a symbiotic union of universities with private higher education providers, is evident (Padro \& Nair, 2016).

In light of this, an international and national perspective of private and state higher education provisioning will be presented to explain the attitudes, contestations and opportunities, with a view to understanding these contestations and opportunities so that partnerships can be built and strengthened to support a single goal of inclusivity.

\section{International Perspective}

The European Consortium for Accreditation PHEIs that are financed, funded or subsidised from the different levels of government, are Austria (regional), France (local), Germany (federal), Netherlands (no state funding but religious PHEIs are subsidised by national government), Norway (partially funded by the state), Poland (no public funding but subsidies are possible), Spain (not funded by the state, but with exceptions), and Switzerland (no public funding). All European countries have to comply with national rules including accreditation from respective bodies.

\subsection{Australia}

In Australia, Deakin University was formally established in 1974 as one of the first public universities in the country to specialise in distance education. After numerous deliberations, they have now re-imagined their programmes for a digitally leveraged environment and are progressively revitalising their campuses as stylish, technology- rich places that make it easier for students to connect with each other, their teachers and the university (Deakin, 2016). This demonstrated commitment to inclusive societies, life-long learning, flexibility and accessibility led to the strategies that were undertaken to provide students with real choices about how, when and where learning occurs. Their focus was on the use of technology in delivering distance education and on lifelong learning undertaken by Deakin via its partnerships, particularly with professional associations (Back \& Davis \& Olsen, 2012). 


\section{Macrothink}

This strategy, in terms of new technologies, had a positive impact on the university's partners in industry, government, professional associations and professions, the workforce and the community national and internationally, and workplace students in Australia, as it made continuing professional education available and accessible. It also benefited students internationally who have studied in Australia by facilitating and upgrading their qualifications, and served as a model of good practice internationally for delivery of lifelong learning.

Distance learning through Deakin offers a range of programmes. This philosophy of inclusivity, life-long learning and access, has made studying online through distance learning in Australia, a popular and successful option. It allows one to adjust one's study and learning schedule to fit one's own needs and requirements, with great flexibility for whatever academic program one chooses to pursue.

\subsection{Malaysia}

In Malaysia, while the delivery of higher education used to be exclusively for the public sector. legislative changes in 1996 led to the coexistence of public and private HEIs. In 2007, there were only 20 public universities compared to more than 500 private institutions; 30 of these are currently categorised as universities or university colleges. Looking at their respective roles as higher education providers, public and private institutions display characteristics of being substitutes while at the same time serving complementary roles to each other. This relationship could be seen as inclining towards a hybrid model that allows both to operate within a single system of higher education provision in the country. Such a hybrid model is evident in how the clientele is divided between public and private higher institutions. It is also evident in the different roles played by faculty members as well as in the programmes being made available in both types of institutions (Chang Da, 2007).

\subsection{India}

The Indian higher education system, one of the largest in the world, has 14,6 million students enrolled in more than 31,000 institutions. However, it is faced with three fundamental challenges - access, equity and quality.

While the public sector has historically dominated the HE landscape, the role of the private sector has increased significantly over the last decade, with the majority of students currently enrolled in private institutions. This is because private HEIs are more demand-driven, customer-oriented, innovative, and diverse, with life-long learning and better success rates. Moreover, the private sector can be credited with the establishment of some globally renowned institutions that have established state-of-the art infrastructure and impart world class education. Going forward, the role of the private sector can be expected to assume greater significance in establishing quality higher education institutions (FICCI, 2011).

\section{National Perspective - How is South Africa Dealing with This Issue?}

During the 1990s, foreign universities flooded the newly democratic South Africa in their scores, but most pulled out after being confronted by rigorous accreditation and registration 
processes, leaving the small but influential and increasingly stable private tertiary sector dominated by local groups (Macgregor, 2008). Today, in contrast to the 25 public HEIs in SA, there are 96 private higher education institutions operate legally and are registered in South Africa. 30 have provisional status (DHET, 2015/2016-2019/20). Some observations can be made about this state of affairs: Although there are far more private than public HEIs, the private sector has far fewer students. In private HEIs, quality and regulation are very important (Macgregor, 2008).

The government and public sector have over the years, been alarmed and feared that the private providers would attract students away from the public universities in the areas where they could generate some income, undermining sources for cash strapped universities and threatening the future of a strong sector built up over decades. At the same time, parents were increasingly concerned about sending their children to the volatile campuses of public universities, as well as the lowering of standards when the public sector opened its doors to disadvantaged students between 1990-1994.

The private higher education boom in 1990s took the country by surprise and there was no framework in place to register, accredit or quality-assure the sector. The Department of Education then set about constructing one, through the Higher Education Act of 1997 and Regulations for the Registration of Private Higher Education Institutions, gazetted in 2002.

These legislative changes created registration, accreditation and quality systems for private institutions. At the global level, South Africa put up a fight against the inclusion of education in the services section of the World Trade Organization's General Agreement in Trade and Services, concerned that it would force the scrapping of its new private sector regulations and systems and open developing countries up to predatory activities by rich world universities Macgregor, 2008) notes that while the new obligations which were forced on private institutions were reasonable, they were also onerous. All institutions granted registration had to obtain initial accreditation from the South African Qualifications Authority, which operates the National Qualifications Framework. Further accreditation is then required from the Council on Higher Education, followed by registration with the Department of Higher Education and Training.

Despite the numerous contestations and ongoing dialogue around the growth of private higher education in South Africa the registration of private higher education institutions continued. Some are: AAA School of Advertising, Animation School (Pty) Ltd, Boston City Campus and Business College (Pty) Ltd, Christ Baptist Church Seminary, Cornerstone Institute, Durbanville College, Global School of Theology, Varsity College, Regent Business School, Oval International, Damelin and the Management College of Southern Africa.

\section{Recognised National Private Higher Education Institutions}

\subsection{Damelin}

Damelin, a private college founded by Benjamin Damelin in 1943, has approximately 17 
campuses across South Africa, Eastern Cape, Free State, Gauteng, KwaZulu-Natal and Western Cape. By November 2012, over one million students had graduated from Damelin, which was lauded by a then prominent South African businessman, Cyril Ramaphosa, for its vital role in educating the nation. Its mode of delivery is distance learning, part-time/full-time and through correspondence. Damelin, accredited as sole South African partner to Oxford Brookes University in the UK, is also a proud affiliate of the London College of International Business Studies (Damelin, 2013).

As a fully registered private HEI, Damelin has also participated in many community activities, including marches against rape and violence against women, bursary support for the financially needy and safe use of the oceans.

\subsection{Varsity College}

Varsity College, a registered private tertiary education institution, was founded in 1991 and forms part of the Independent Institute of Education (IIE). The IIE is a wholly owned subsidiary of South African investment holding company ADvTech Group Limited, responsible for developing, assessing, certifying and overseeing the delivery of curricula at Varsity Colleges across approximately eight campuses. Their mode of delivery includes full-time/part-time, and distance education.

\subsection{Helderberg College}

Helderberg College is a registered private HEI situated in Somerset West, Cape Town. It was established in 1893 in North America and moved in 1928, making it the oldest Adventist college on the continent of Africa. It is part of the Seven-day Adventist education system, the world's second largest Christian school system

The campus hosts the College, as well as a Pre-School, Primary School and High School, with accommodation. It takes community engagement very seriously, and supports an olive oil industry.

\section{Characteristics and Strengths of Private Higher Education Institutions (PHEI)}

It would be interesting to know more about the reasons for the existence and growth of PHEIs. They are here to stay and it is important to identify the possible strengths but also risks and in order to cope with them adequately. How do they contribute to Higher Education in SA? The European Consortium for Accreditation (ECA, 2010). is informative, and distinguishes a number of specific characteristics of PHEIs:

They are demand-driven: many PHEIs are established because of specific demands from the labour market. Employers, corporates and even governments may have specific wishes for education of their staff, especially after they have been working for a few years. Private institutions are ready to react to these wishes and are more customer-oriented.

They support and are examples of innovation: PHEIs seem to have more possibilities 
to develop innovative ways of teaching and learning. They have less trouble with vested interests, which may paralyze innovation. Some experiences suggest that PHEIs are therefore drivers for innovation, both in pedagogical methods and in content of programmes.

They take on all types of students: A large number of public HEIs are still mainly focused on their traditional clientele who are young students between the ages of 18-25 years. Most of these HEIs have trouble organising themselves to be able to deliver programmes for "other" types of students: those who work, who combine vocations with studies, women entering the labour market after motherhood, etc. PHEIs seem better able to respond to the specific needs of these types of students.

They support life-long learning: PHEIs seem better inclined to open up to the necessity of lifelong learning. It might be true that students in their initial year of studies are taught to develop an attitude of "learning to learn" and continuous development", but in reality, the same HEIs that teach those attitudes are unable put it in practice. PHEIs are more ready and able to react directly and quickly to new questions and demands by offering courses, programmes, trainings, executive courses, modules, etc.

They display higher success rates: In some cases, it is remarkable to see that PHEIs seem more efficient and effective than public HEIs. In quite a number of cases, the number of students that receive their qualifications exceed those at HEIs and the duration of the period of study appears to be better than those in public HEIs. The customer-oriented attitude of PHEIs will stimulate these results, but the way in which PHEIs have to take care of their finances might have led to more effective teaching methods as well.

\section{Research Methodology}

A case study research method was utilised, using a private higher education institution, namely, "Institution Y". The empirical part of the search focused on engaging in focussed dialogue with some of the directors based on their experience of private and public higher education. Information on the internationalisation of private higher education was retrieved, specifically, through directed questions, and by document analysis on the internationalisation of Higher education in SA. In the theoretical literature review, data was accessed from the internet, and from journals, books and articles on the internationalization of higher education.

\section{Themes Uncovered}

The primary objective of higher education is to provide educational services to all its citizens. While higher education strives for inclusivity, quality and lifelong learning, they are different in their modes of delivery. With conceptualisation, comes an exercise that questions why public and private institutions are not talking with one voice. To unite these giants, one needs to interrogate how conceptualisation, agility and foot-printing will promote a united higher 
education system in South Africa. Research revealed discussion around three themes, which are presented as arguments, with reference to the case study, Institution "Y".

\subsection{Conceptualisation}

The first argument centres around Conceptualisation. What is the difference between private and public higher education? How has that come about? There seem to be two major constructs that divide the public and private higher education institutions:

The Financial/Funding Model which finances these kinds of institutions. The public HEIs are subsidised by the state, while private HEIs are self-funded.

The operational flexibility model of the institutions with a Business Model that frames private higher education operations and which public higher education institutions are now aspiring to, largely because of the new concepts of ideas and policies that are driving public HEIs, for example, performance management systems, pastoral care systems, financial management systems, management information systems and new public management systems.

While the award of qualifications for recognition of learning achieved and the contribution to knowledge development are the key outcomes of higher education which both institutions offer, the conceptual divide between public and private institutions needs to be reviewed from this perspective rather that the traditional financial and business model perspective which divides the two. In this way, the aspiration reflected in SDG 4 would be attainable more efficiently and in a shorter period of time. Private higher education institutions accommodate students from all racial groups and geographic regions across Africa as well as globally. The data on private higher education institutions is sparse; however, observations and perceptions indicate that private higher education institutions are equally or more efficient in providing a learning environment that promotes, sustains and qualifies graduates.

\subsection{Foot-printing}

The second argument relates to foot-printing, which brings an international perspective to higher education. Public higher education institutions in South Africa exist with little imprint in global spheres, largely through institutional linkages with international institutions. "Institution Y" has established footprints in a number of countries outside the borders of South Africa. The funding element that sustains private higher education institutions has largely driven private higher education institutions to set up satellite campuses or support offices in other countries. This financial driver has, inadvertently, influenced the academic offerings within private higher education institutions, bringing an international influence in curriculum offerings, organisational management and international academic staff and students. This unintended outcome of private higher education fits appropriately within the conception of internationalisation of higher education which includes curriculum, human resources, governance and knowledge development opportunities through international influences. By setting up those spaces, PHEIs are also influenced by the context within which they operate. In other words, if they are in Zambia, they are influenced by the challenges and opportunities that Zambia presents in a global space and these influences shape what happens in the local space 
of South Africa. By actually having footprints in international spaces, they can bring in to their program design and address international issues that they come to experience first-hand and can therefore provide necessary competences, experience and opportunities to be globally competitive. According to Murphy (2000: 4), should one want to make progress in any field of endeavour, one must discover a working basis that is universal in its application.

\subsection{Agility}

The third argument is related to agility. Private HEIs are more customer-oriented, quicker to respond to global changes and able to adapt their program offerings in a much quicker response time than Public HEIs. The European Consortium for Accreditation (ECA 2010: 5) confirms that since the majority of private higher education institutions is dependent on all types of private funding and fees, they tend to listen more to their students and treat them as customers. The satisfaction of the students with the private higher education institutions is in general at a high level. Private higher education institutions have to satisfy their customers since they may discontinue their studies and move to another institution. This loss of income might influence the existence of the private higher education institution. Having the agility to respond to global discourses and changes quickly, and establishing partnerships with public higher education, can strengthen their relevance, credibility and alignment with global standards of higher education offerings that can promote recognition, transferability and portability of programmes and modules on a global scale. In this respect, private higher education institutions like "Institution Y" have developed the followings partnerships that can promote its footprint, sustain agility and create stronger relationships in offering higher education within an international arena:

In keeping with the objectives of Private Public Partnership (PPP) which normally encapsulates government, civil society, business and academia, and adding to the existing scenario at some private higher education institutions, "Institution Y" has further strengthened this objective by engaging with regional and national partners, such as Durban University of Technology (DUT), University of Witwatersrand (WITS), Durban Chamber of Commerce and Industry (DCCI) and Durban Tourism, as indicated on its website. Furthermore, with the sharing of websites, "Institution Y" has also partnered with Durban Tourism for the purpose of mutual marketing and advertising.

These partnerships have multiple spinoffs with varying benefits. They add value to the development of stakeholder engagement. Besides influencing an institutional stakeholder relationship, several Memoranda of Understandings have increased the sharing of core academic activities like examiners, markers, moderators, invigilators and supervisors.

During the formative years of "Institution Y", it established a collaborative arrangement with a public institution based in Europe. It was pro-active in collaborating with a public university in order to exchange academics and administrators, establish joint multidisciplinary/co-supervised collaborative programmes, and share joint presentations and publications. 
"Institution Y" engages with existing affiliations like the South African Business Schools Association (SABSA), the African Association of Business Schools (AABS) and the National Association of Distance Education Organisations of South Africa (NADEOSA). These affiliations add institutional value from an operational and academic excellence point of view and exemplify strategic collaborations. How does this promote Internationalisation? In aligning with common key business affiliates, "Institution Y" has strengthened its reach nationally and explored more possibilities around information sharing, conference attendance, joint paper presentations, participation in round-table dialogues and colloquia. With the collective of all national affiliates it has formed a national network of business providers, similar to the Federation of Indian Chambers of Commerce and Industry, thereby increasing its footprint nationally and internationally.

\section{Themes in Relation to South Africa}

How is conceptualisation, footprint and agility promoting internationalisation towards SDG 4 in SA?

South Africa, in its quest to be the preferred destination of choice to study and research, has to discover a working basis that is universal in its application. With the demand for access to higher education which exceeds places available at public higher education institutions, South Africa needs to re-evaluate its role as an educational services provider to aspire to SDG4, which is "To ensure inclusive and equitable quality education, and promote lifelong learning opportunities for all".

In order for South Africa to showcase a united higher education front, it has to accomplish a number of things:

Re-conceptualise and benchmark best practices in awarding qualifications for recognition of learning and contributions to knowledge development

$>$ Increase international footprints in international spaces, by including new knowledge into program design and addressing international issues that private higher education institutions experience first-hand

$>$ By being open, transparent, inclusive and consistent in advertising and marketing of all legitimately registered higher education institutions within all official documentation emanating from the Department of Higher Education and Training, like the National Development Plan and the Strategic Plan.

Setting up a higher education communication network for potential students to have the freedom of choice in selecting study programmes nationally and internationally, given the shortage and continuous closure of public higher education institutions.

$>$ Following the likes of Australia, Malaysia, India, Japan and the United States of America in understanding of the opportunities and successes around distance learning, new 
technology, lifelong learning, hybrid approach learning, addressing of potential government measures for implementation and the stabilising of private higher education.

$>$ Observing the European Consortium for Accreditation in how PHEIs are financed, funded or subsided from the different levels of government through negotiation seeing that there are approximately 96 private higher education institutions legally registered and accredited in South Africa.

$>$ Embracing the potential strength of private higher education in terms of demand-driven, customer-oriented, innovation, diversity of students, lifelong-learning, success rates justifies the importance of its existence.

$>$ Diversifying provision based on open learning principles to improve learning opportunities across HE by expanding and strengthening the options available.

\section{Conclusions}

The potential impact and influence of private HEIs on the internationalisation of higher education can only be in line with SDG 4 if re-conceptualisation, increasing the international footprint and agility, is driven aggressively for the greater good of the South African higher education system.

On evaluating perceptions of the gaps that exist between private and public higher education institutions, and given the experiences of Institution " $Y$ ", it is imperative for SA to unify these two sectors by acknowledging that the demand for access to higher education exceeds places available and that there are too few public institutions. The importance and influence of private higher education in South Africa, thus cannot be overlooked.

In making the SDG 4 a strategic objective, higher education would have to be more open by diversifying provision based on open learning principles like those in Australia, Malaysia and India, to improve learning opportunities by expanding and strengthening distance education landscapes. This would increase its international footprint with multiple positive outcomes.

\section{References}

Alfred, B. Lewis, Jr. \& Bernard, L. (2013). [Online] Available: http://www.tandfonline.com/doi/abs/10.1080/00107530.1973.10745277?journalCode $=\mathrm{u}$ ucp20 (Retrieved October 12, 2018).

Altbach, G. P. (2005). Global Perspectives on Higher Education: Private Higher Education: A Global Revolution, Sense Publishers, Rotterdam/Taipei. p. 1.

Australian Distance Learning. (1998-2016). Retrieved September 12, 2018 from $\mathrm{http} / / \mathrm{www}$. australianuniversities.com.au/distance-learning/

Back, K., \& Davis, D., \& Olsen, A. (1996). Internationalization and Higher Education: Goals 
and Strategies, Australian Government Publishing Service, Canberra.

Bakker, A. (2014). Job Demands-Resources Theory. https://doi.org/10.1002/9781118539415.wbwell019

Chang Da, W. (2007). Public and Private higher education institutions in Malaysia: Competing, Complementary or Crossbreeds as Education Providers. Kajian Malaysia, Jld. XXV, No. 1.

Damelin Private College. (1943-2013). What does Damelin stand for? Retrieved October 20, 2013 from https://www.damelin.co.za/about-us/what-does-damelin-stand-for?

Deakin University (Australia). (2016). Our history at a glance (2016). Retrieved October 15, 2016 from http://www.deakin.edu.au/about-deakin/reputation/history

Dittrich, K., \& Weck-Hannermann, H. (2010): Private Higher Education Institutions and Quality Assurance, European Consortium for Accreditation in Higher Education, Europe. A discussion paper.

Federation of Indian Chambers of Commerce and Industry (FICCI): Higher Education Summit (2011). Private Sector participation in Indian Higher Education, New Delhi, India.

Government of Republic of South Africa (RSA). (2018). National Development Plan (NDP) (2030): Our future - make it work, National Planning Commission, The Department of the Presidency, Republic of South Africa.

Government of Republic of South Africa (RSA). (2018). Register of Private Higher Education Institutions last update (2018). Retrieved 8 July, 2018 from http://www.dhet.gov.za/Registers_DocLib/Register

Government of the Republic of South Africa. (RSA). 2018. Department of Higher Education and Training Strategic Plan 2015/16-2019/20. Retrieved May 24, 2018 from http//www.dhet.gov.za/Strategic Plan for Fiscal years

Helderberg College (2016). Retrieved October 17, 2016 from http://www.hbc.ac.za

Knight, J. (2015). Updating the Definition of Internationalization, International Higher Education, Issue 33, Boston). p. 1.

Macgregor, K. (2008). Private higher education stabilizes. University World News, Issue No. 27.

Middlehurst, R. (2016). Privately funded higher education providers in the UK: The changing dynamic of the higher education sector. Kingston University, London, United Kingdom. https://doi.org/10.1016/B978-0-08-100872-0.00005-7

Murphy, J. (2001). The Power of your Subconscious Mind, published by Bantam books, USA. p. 4.

Padro, F. F., \& Nair, C.S. (2016). Higher Education: The needs of the many outweigh the needs of the few. https://www.sciencedirect.com/science/article/pii/B9780081008720000197 


\section{Macrothink}

Regent Business School, Breaking Barriers: Private Providers can widen access to higher education: A fertile idea whose time has come. Regent Business School, Durban, South Africa, Press Release, 29 January 2014. Retrieved January 29, 2018 from http//studymagazine.com/wp-content/uploads2011/03breaking-barriers

Republic of South Africa, Small to Medium Enterprises (SME). (2015). Entrepreneurs. Retrieved August 16, 2018 from http:/www.smesouthafrica.co.za/The-top-5-sectors-forSA-entrepreneurs

United Nations, (UN), Report of the Secretary-General, (2017). "Progress towards the Sustainable Development Goals". Retrieved July 28, 2018 from http//sustainabledevelopment.un.org/sdg4

Varsity College. (2016) Who is IIE? Retrieved October 20, 2016 https://www.varsitycollege.co.za/independent-institute-of-education.aspx

\section{Copyright Disclaimer}

Copyright for this article is retained by the author(s), with first publication rights granted to the journal.

This is an open-access article distributed under the terms and conditions of the Creative Commons Attribution license (http://creativecommons.org/licenses/by/3.0/). 